\title{
Predation by diving ducks on the biofouling mussel Musculista senhousia in a eutrophic estuarine lagoon
}

\author{
Masumi Yamamuro ${ }^{1, *}$, Nariko $\mathrm{Oka}^{2}{ }^{2}$ Jun'ichi Hiratsuka $^{3}$ \\ 'Marine Geology Department, Geological Survey of Japan, 1-1-3 Higashi, Tsukuba, Ibaraki 3058567, Japan \\ ${ }^{2}$ Yamashina Institute for Ornithology, Konoyama, Abiko, Chiba 2701145, Japan \\ ${ }^{3}$ Shimane Research Group of Wild Life, c/o Dr. Iwao Sakamoto Department of Medicine, Shimane Medical University, \\ 89-1 Enyamachi, Izumo, Shimane 6938501, Japan
}

\begin{abstract}
The effect of predation by diving ducks (Aythya fuligula, Aythya ferina, and Aythya marila) on filter-feeding bivalves was evaluated in eutrophic estuarine lagoons, Lakes Nakaumi and Shinji, in Japan. Bivalves take up nutrients in the form of phytoplankton and detritus. Winter-migrating diving ducks feed on these bivalves during the cold season. In Lake Nakaumi, diving ducks chiefly consumed the biofouling mussel Musculista senhousia. The biomass of $M$. senhousia decreased markedly at most sampling points during duck wintering, averaging $1126 \mathrm{~g} \mathrm{~m}^{-2}$ (wet weight) at 42 sampling points in November 1996 and $24 \mathrm{~g} \mathrm{~m}^{-2}$ in March 1997 The amount of nitrogen in $M$. senhousia eaten by ducks during winter was estimated at $52 \mathrm{t}$ and phosphorus at $3.8 \mathrm{t}$. In the absence of ducks, $M$. senhousia death in summer would add equivalent nitrogen and phosphorus loads to the lagoon. The decomposition of $M$. senhousia in summer when water mixing is weak would also accelerate oxygen depletion at the lagoon bottom. Mussel predation by wintering ducks would therefore decrease unfavorable effects of biofouling mussel decomposition in summer when nuisance phytoplankton blooms and anoxia occur easily.
\end{abstract}

KEY WORDS: Nitrogen Phosphorus Aythya fuligula Aythya ferina Aythya marila - Musculista senhousia Corbicula japonica Lake Nakaumi · Lake Shinji

\section{INTRODUCTION}

Aquatic birds are top-level consumers in many shallow-water areas, feeding largely on fish and macroinvertebrates. Because of the large biomass and enormous population, they may alter the standing crop of prey and play an important role in nutrient flux (Erwin 1996).

Most duck species depend almost exclusively on shallow-water habitats. Increased human activity in coastal areas generally reduces the use of shallowwater areas by duck species. The wintering place for diving ducks in the Nakdong River Estuary, Korea, for example, was lost during the 1980 s because of barrage

•E-mail: yamamuro@gsj.go.jp and reclamation projects (Doornbos et al. 1986, Kim \& Won 1994). The diving duck population in the U.S. also decreased, presumably because of human impact (Perry \& Deller 1996).

Three species of diving ducks-Aythya fuligula (tufted duck), Aythya ferina (pochard), and Aythya marila (scaup)-winter in the eutrophic estuarine lagoons of Lake Nakaumi (area $86.8 \mathrm{~km}^{2}$, mean depth $5.4 \mathrm{~m}$ ) and Lake Shinji (area $79.2 \mathrm{~km}^{2}$, mean depth $4.5 \mathrm{~m}$ ) in Japan. The diving duck population is generally more than 5 times larger in Lake Nakaumi than in Lake Shinji. Based on data counted on the day of the nationwide New Year's bird count in Japan, the average population and standard deviation of Aythya spp. in the period 1986 to 1995 was $50276 \pm 14493$ in Lake Nakaumi and $8744 \pm 2115$ in Lake Shinji (Wild 
Bird Society of Japan. Shimane Prefecture Branch unpubl.). Both lakes are similarly eutrophic. Total nitrogen concentration is 400 to $550 \mu \mathrm{g} \mathrm{l} \mathrm{l}^{-1}$ in both lagoons. The total phosphorus concentration is 30 to $50 \mu \mathrm{g} \mathrm{l}^{-1}$ in Lake Shinji and 40 to $65 \mu \mathrm{g} \mathrm{l}^{-1}$ in Lake Nakaumi (Kato et al. 1996), Shallow basin areas where bivalves, the ducks' main food source, survive are similar.

In Lake Nakaumi, the most dominant macrobenthos is the biofouling Asian mussel Musculista senhousia (Sawamura et al. 1993); the infaunal commercial clam Corbicula japonica dominates in Lake Shinji (Nakamura et al. 1988). M. senhousia is a thin-shelled mytilid that lives in the intertidal and subtidal soft sediments of bays and estuaries, where it weaves a cocoon by binding sediment with its byssal threads. Where the mussel lives in high densities, these cocoons are woven together to create a byssal mat, thereby altering the nature of the sediment inhabited by commercial infaunal bivalves. Since neither $M$. senhousia nor $C$. japonica survives in anoxic conditions, their distributions are restricted to the shallower parts of each lagoon (Nakamura et al. 1988, Sawamura et al. 1993). These bivalves are probably the chief prey of diving ducks.

Such predation would contribute to the removal of biofouling mussels from the lagoon. Several studies have shown that bivalves are the most important food source for wintering diving ducks (e.g. Stańczykowska et al. 1990, De Vaate 1991). The effect of predation, however, may not significantly alter the bivalve biomass (Sewell 1996, Hilgerloh 1997). Nitrogen and phosphorus contributed by aquatic birds may degrade lagoon water quality (Manny et al. 1994, Marion et al. 1994).

Our purpose was to (1) examine the importance of bivalves as duck prey, (2) estimate the number of biofouling mussels removed by ducks through predation, and (3) deduce the possible effects of mussel predation by ducks on lagoon water quality.

\section{METHODS}

Duck diet and nutrient concentrations. We collected dead Aythya fuligula, $A$. ferina, and $A$. marila accidentally caught in fisheries' gill nets in Lake Nakaumi and Lake Shinji (Fig. 1) between October 1994 and March 1995, and examined duck nitrogen and phosphorus concentrations, whole body and gizzard weight, and digestive organ content. Gill nets were usually set for half a day, and drowned ducks found when nets were taken in were immediately frozen until dissected. Gender was identified by genitalia. Digestive organ content was removed and fixed with buffered formalin $(10 \%)$ for later identification. The weight of content

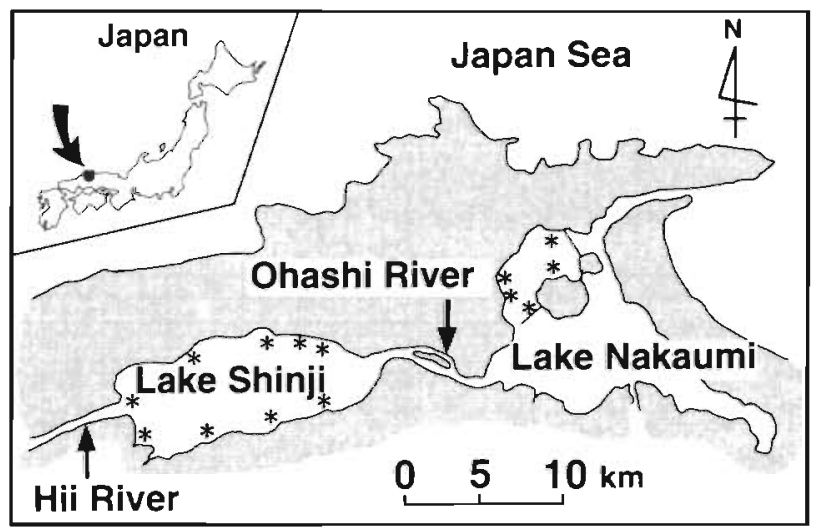

Fig. 1. Location of Lakes Nakaumi and Shinji (Japan), (*) Locations of gill nets

was subtracted from the whole body weight of ducks. Pectoral muscle, liver, and the whole body (excluding feathers, wing/leg bones, head, and intestine) of ducks were freeze-dried, powdered using a mill, and analyzed for nitrogen and phosphorus.

Bivalve nutrient concentrations and caloric values. Organic carbon, nitrogen, and phosphorus concentrations and weight of Musculista senhousia sampled at the east end of the Ohashi River (Fig. 1) were determined monthly from October 1994 to March 1995. To determine caloric values, $M$. senhousia and Corbicula japonica were sampled at the east end of the Ohashi River in October and November 1994 and the north shore of Lake Shinji in March 1995.

Bivalves were sampled with a Smith-McIntyre grab sampler $\left(22 \times 22 \mathrm{~cm}^{2}\right)$ and sieved in a nylon bag (mesh: $0.5 \mathrm{~mm}$ ) on the boat. They were rinsed quickly with deionized water in the laboratory, selected randomly for weighing, and freeze-dried. Dried flesh was removed using forceps, and dried flesh and shell were weighed separately. Dried flesh for analyzing organic carbon, nitrogen, phosphorus, and caloric value was powdered and homogenized using an agate mortar and pestle.

Analytical methods. Organic carbon and nitrogen were determined using an elemental analyzer (Yanaco CHN corder MT5). Total phosphorus was determined colorimetrically with a Technicon Autoanalyzer using the molybdate blue method (Technicon Industrial Method No. 155-71W) after digestion using an autoclave $\left(121^{\circ} \mathrm{C}\right.$ for $\left.3 \mathrm{~h}\right)$ in potassium persulfate $\left(6.7 \mathrm{~g} \mathrm{I}^{-1}\right)$ and sulfuric acid $(0.25 \mathrm{~N})$. The caloric value was determined using a bomb calorimeter (Shimadzu CA-4P), using about $10 \mathrm{~g}$ of powdered samples.

Mussel biomass. Musculista senhousia biomass in Lake Nakaumi was studied along 14 transects (Fig 2) in November 1996 and March 1997. Sediment $\left(0.1 \mathrm{~m}^{2}\right)$ was collected using a Smith-McIntyre grab sampler 


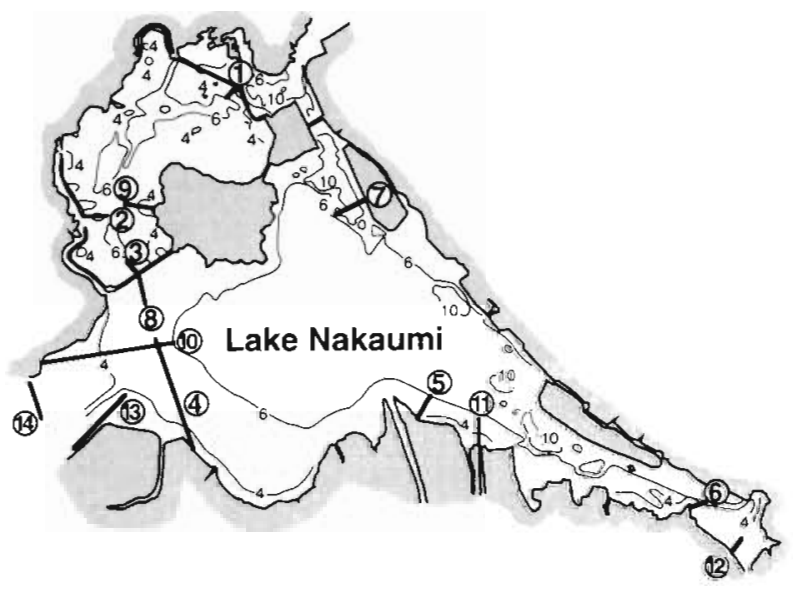

Fig. 2. Transects along which sediment sampling was conducted to count Musculista senhousia biomass in Lake Nakaumi. Water depth is in meters

every $1 \mathrm{~m}$ of depth along the transect and sieved in a nylon bag (mesh: $0.5 \mathrm{~mm}$ ) on the boat. At each transect, the position of the boat was first determined with GPS, then moved slightly to the planned depth. Sam-

Table 1. Aythya spp. Comparison of gizzard weight ( $g$; mean $\pm \mathrm{SE}$, number in parentheses) of wintering diving ducks for lakes and gender. Significant differences were analyzed by unpaired t-test

\begin{tabular}{|lcccc|}
\hline Lakes & Lake Nakaumi & Lake Shinji & $\mathrm{p}$ \\
\hline A. fuligul & $38.9 \pm 4.7(8)$ & $70.2 \pm 3.0(20)$ & $<0.0001$ \\
A. ferina & $37.0 \pm 1.9(21)$ & $77.9 \pm 7.6(3)$ & $<0.0001$ \\
A. marila & $30.9 \pm 0.8 \quad(5)$ & $84.5 \pm 4.2 \quad(9)$ & $<0.0001$ \\
Gender & Male & Female & $\mathrm{p}$ \\
\hline A. fuligul & $67.0 \pm 5.0(16)$ & $53.7 \pm 4.9(12)$ & 0.073 \\
A. ferina & $44.3 \pm 4.7(15)$ & $38.4 \pm 4.6(9)$ & 0.412 \\
A. marila & $58.6 \pm 13.8(6)$ & $70.4 \pm 8.8(8)$ & 0.463 \\
\hline
\end{tabular}

pling was not done at the bottom where depth was irregular due to potential dredging problems. Macrobenthos was separated from the residue within a day in the laboratory. The wet weight of $M$. senhousia was determined after removing the byssal threads.

\section{RESULTS}

Digestive organ content suggests that Aythya spp. collected from Lake Nakaumi and Lake Shinji chiefly consumed the bivalves dominant in each lake. More than $90 \%$ of $A$. fuligula caught in gill nets in Lake Nakaumi $(\mathrm{n}=14$ ) contained only Musculista senhousia in their digestive organs, while $80 \%$ of A. fuligula caught in Lake Shinji $(\mathrm{n}=29)$ contained only Corbicula japonica (shells without flesh were not counted). Likewise, $62 \%$ of $A$. ferina caught in Lake Nakaumi ( $\mathrm{n}=$ 21) contained only $M$. senhousia, while the 3 individuals caught in Lake Shinji contained only C. japonica. All $A$. marila caught in Lake Nakaumi $(n=5)$ contained $M$. senhousia and small amounts of a bivalve, Tapes philippinarum, and all individuals $(\mathrm{n}=9)$ caught in Lake Shinji contained only $C$, japonica.

No significant difference in body weight was seen between lagoons or gender for all Aythya spp. ( $\mathrm{p}>$ 0.075 by unpaired $t$-test). The gizzard weight of Aythya spp. caught in Lake Shinji was double that of species caught in Lake Nakaumi (Table 1), although the difference in gizzard weight between genders was negligible (Table 1).

Temporal changes in the amount of nitrogen and phosphorus per individual studied for Aythya fuligula (Fig. 3) increased from October to March, although they varied greatly, presumably because of the small number of specimens limited by the sample collection method.

Musculista senhousia tripled in flesh dry weight from October to March (Table 2). The relative density

Table 2. Musculista senhousia. Changes in weight and carbon, nitrogen, and phosphorus content of mussels collected at the east end of the Ohashi River from October 1994 to March 1995. Mean and SD of weight were calculated with 10 randomly selected individuals. About 200 individuals were powdered and homogenized for carbon, nitrogen, and phosphorus measurements determined 3 times

\begin{tabular}{|c|c|c|c|c|c|c|c|c|c|c|c|c|}
\hline \multirow[t]{2}{*}{ Month } & \multicolumn{2}{|c|}{$\begin{array}{c}\text { Total wet weight } \\
\text { per individual } \\
\text { (mg) }\end{array}$} & \multicolumn{2}{|c|}{$\begin{array}{l}\text { Flesh dry weight } \\
\text { per individual } \\
\text { (mg) }\end{array}$} & \multicolumn{2}{|c|}{$\begin{array}{c}\text { Shell weight/Total } \\
\text { wet weight } \\
(\%)\end{array}$} & \multicolumn{2}{|c|}{$\begin{array}{l}\text { Flesh carbon } \\
\qquad(w t \%)\end{array}$} & \multicolumn{2}{|c|}{$\begin{array}{c}\text { Flesh nitrogen } \\
(\text { wt } \%)\end{array}$} & \multicolumn{2}{|c|}{$\begin{array}{c}\text { Flesh } \\
\text { phosphorus } \\
\left(\mathrm{mg} \mathrm{g}^{-1}\right)\end{array}$} \\
\hline & Mean & $\mathrm{SD}$ & Mean & SD & Mean & SD & Mean & $\mathrm{SD}$ & Mean & $\mathrm{SD}$ & Mean & $\mathrm{SD}$ \\
\hline October & 274 & 85 & 9.39 & 2.60 & 27.8 & 5.8 & 48.6 & 0.68 & 9.42 & 0.12 & 7.24 & 0.22 \\
\hline November & 379 & 130 & 16.6 & 7.13 & 28.2 & 7.1 & 44.8 & 0.11 & 8.70 & 0.01 & 6.26 & 1.08 \\
\hline December & 493 & 157 & 24.0 & 7.92 & 26.7 & 2.4 & 44.9 & 0.98 & 8.70 & 0.20 & 6.77 & 0.18 \\
\hline January & 414 & 93 & 18.9 & 4.46 & 28.0 & 2.1 & 41.7 & 0.02 & 8.36 & 0.03 & 5.75 & 0.25 \\
\hline February & 450 & 96 & 25.3 & 4.03 & 29.8 & 3.3 & 39.4 & 0.12 & 7.40 & 0.15 & 5.41 & 0.33 \\
\hline March & 495 & 101 & 29.7 & 7.87 & 29.5 & 3.6 & 37.7 & 0.66 & 7.11 & 0.23 & 5.32 & 0.20 \\
\hline
\end{tabular}



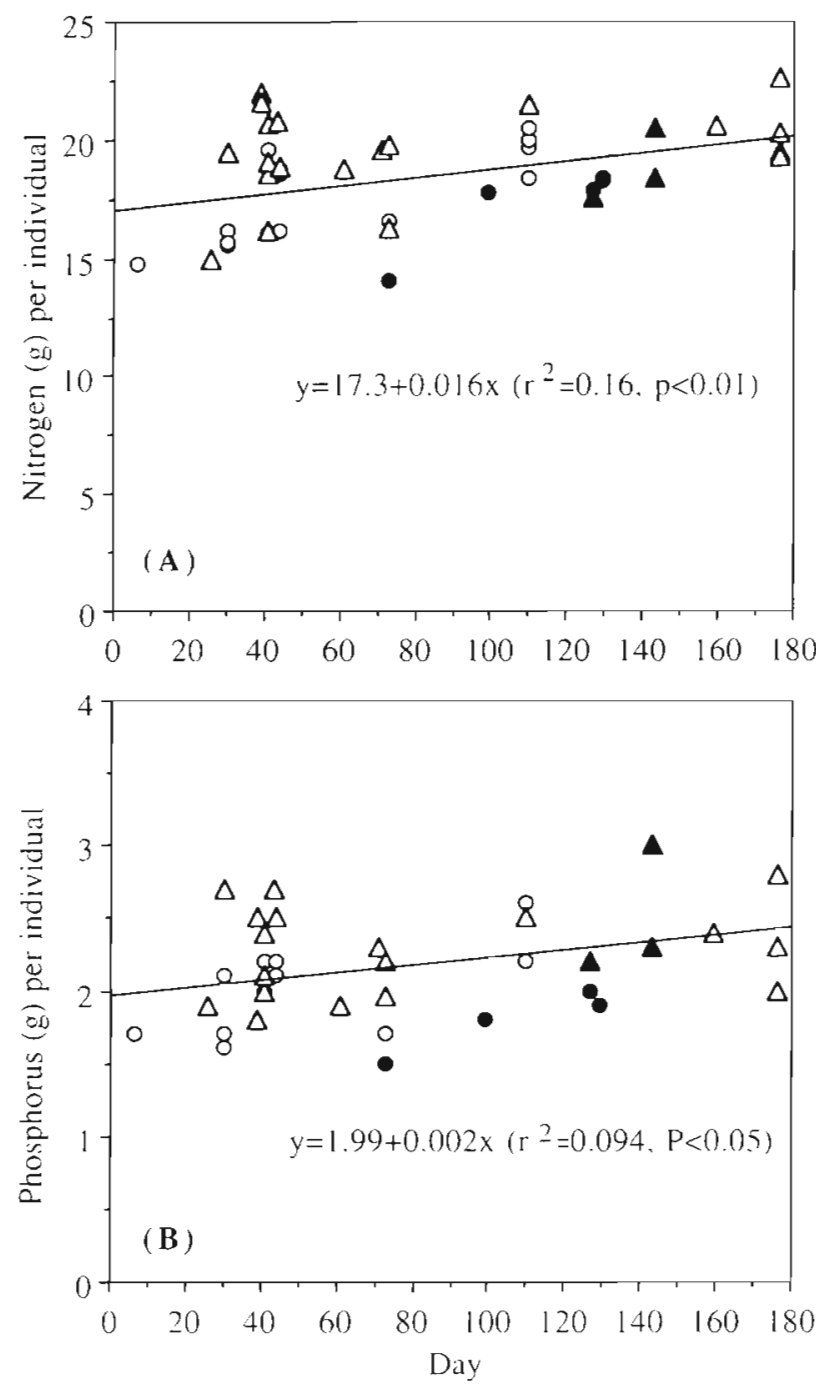

Fig. 3. Aythya fuligula. Changes in nitrogen and phosphorus per individual versus day caught by gill net during winter from October 1994 to March 1995. (@) Lake Nakaumi, female; (ム) Lake Nakaumi, male; (O) Lake Shinji, female; $(\Delta)$ Lake Shinji, male. October 1, 1994 was defined as Day 0. Regressions were calculated for all samples with the day $(x)$ as an independent variable and nitrogen and/or phosphorus as a dependent variable $(y)$ of shell (in Table 2) increased simultaneously. Carbon, nitrogen, and phosphorus contents of dry flesh decreased slightly.

Caloric value of dry Corbicula japonica flesh was $18.0 \mathrm{~kJ} \mathrm{~g}^{-1}$ in October and November 1994 and $18.2 \mathrm{~kJ}$ $\mathrm{g}^{-1}$ in March $1995\left(\right.$ mean $\left.=18.1 \mathrm{~kJ} \mathrm{~g}^{1}\right)$. Corresponding values for Musculista senhousia were 17.3, 17.2, and $18.3 \mathrm{~kJ} \mathrm{~g}^{-1}$ (mean $\left.=17.6 \mathrm{~kJ} \mathrm{~g}^{-1}\right)$.

Presence of Musculista senhousia was observed at 42 of 61 sampling points either in November 1996 or March 1997 (Fig. 4). The $M$. senhousia biomass decreased markedly at most sampling points during wintering by diving ducks. The average and minimum - maximum biomass (wet weight) of $M$. senhousia at the 42 sampling points was 1126 (0 to 5600) $\mathrm{g} \mathrm{m}^{-2}$ in November 1996 and 24 (0 to 435) $\mathrm{g} \mathrm{m}^{-2}$ in March 1997.

\section{DISCUSSION}

Diving ducks in Lake Nakaumi and Lake Shinji chiefly consumed filter-feeding bivalves taking up phytoplankton growing within lagoons. Nutrients in duck excrement would therefore not increase the total (dissolved and particulate) nitrogen and phosphorus in lagoon water. Instead, the amount of nutrients accumulated during their stay would be removed from the water when they leave the lagoons. If the accumulation of nitrogen in any individual Aythya fuligula during its $180 \mathrm{~d}$ stay from October to March is taken to be $2.9 \mathrm{~g}$ and that of phosphorus $0.36 \mathrm{~g}$ (Fig. 3), nitragen and phosphorus accumulated by the average population of A. fuligula in both lagoons (26532 in Lake Nakaumi and 6845 in Lake Shinji for 1986 to 1995 , Wild Bird Society of Japan, Shimane Prefecture Branch unpubl.) would be $97 \mathrm{~kg}$ for nitrogen and $12 \mathrm{~kg}$ for phosphorus. This amount, although small, is removed from lagoons when ducks migrate in spring.

The difference in the gizzard weight of Aythya spp. for Lake Nakaumi and Lake Shinji (Table 1) suggests

Table 3. Estimation on caloric requirement of Aythya spp. wintering in Lake Nakaumi. Mean weight and SD were calculated with samples from this study. Caloric requirement was calculated using conversion of 2.8SMR (standard metabolic rate) of active birds (Kooyman et al. 1982) and an assimilation efficiency of $73 \%$ (Cooper 1980). SMR was calculated from the allometric formula (Lasiewski \& Dawson 1967): SMR $\left(\mathrm{kJ} \mathrm{d}^{-1}\right)=4.184 \times 78.3 W^{0.723}$ where $W$ is bird weight $\mathrm{n} \mathrm{kg}$. The mean population was calculated from data for 10 yr (1986 to 1995. Wild Bird Society of Japan, Shimane Prefecture Branch unpubl.)

\begin{tabular}{|c|c|c|c|c|c|c|}
\hline & \multicolumn{2}{|c|}{$\begin{array}{l}\text { Weight of } \\
\text { duck }(\mathrm{kg})\end{array}$} & \multirow{2}{*}{$\begin{array}{c}\text { Caloric requirement } \\
\text { per individual } \\
\qquad\left(\mathrm{kJ} \mathrm{d} \mathrm{d}^{-1}\right)\end{array}$} & \multicolumn{2}{|c|}{$\begin{array}{l}\text { Lake Nakaumi } \\
\text { population (no of ind.) }\end{array}$} & \multirow{2}{*}{$\begin{array}{l}\text { Caloric requirement } \\
\text { per population } \\
\left.\text { (M.J d } \mathrm{d}^{-1}\right)\end{array}$} \\
\hline & Mean & $\mathrm{SD}$ & & Mean & $\mathrm{SD}$ & \\
\hline Aythya fuligula & 0.867 & 0.089 & 1133 & 26532 & 9416 & 30061 \\
\hline Aythya ferina & 0.993 & 0.151 & 1250 & 18042 & 7577 & 22553 \\
\hline Aythya marila & 1.145 & 0.079 & 1386 & 5702 & 2078 & 7903 \\
\hline Total. & & & & & & 60517 \\
\hline
\end{tabular}


that less effort is needed to digest Musculista senhousia (from Lake Nakaumi), which has a much thinner shell (shell weight/total wet weight $=27$ to $30 \%$, Table 2) than Corbicula japonica (shell weight/total wet weight $=83$ to $85 \%$, Nakamura et al. 1988), and that Aythya spp. do not often move between lagoons. The gizzard weight of Aythya spp. caught in Lake Nakaumi was half that of those caught in Lake Shinji, so we estimated the amount of $M$. senhousia grazed by diving ducks assuming that ducks in Lake Nakaumi ate exclusively $M$. senhousia.

Diving ducks in Lake Nakaumi require Musculista senhousia more to meet energy needs than for nitrogen and phosphorus requirements. The average population of Aythya spp. wintering in Lake Nakaumi would require $60517 \mathrm{MJ} \mathrm{d}^{-1}$ (Table 3). To meet this requirement by feeding on $M$. senhousia, whose caloric value was ca $17.6 \mathrm{~kJ} \mathrm{~g}^{-1}$ in flesh, ducks would have had to ingest $3438 \mathrm{~kg}$ of flesh $\mathrm{d}^{-1}$

Table 4 summarizes the estimated numbers of Musculista senhousia consumed by Aythya spp. in Lake Nakaumi assuming that the average wintering population consumes $3438 \mathrm{~kg}$ of $M$. senhousia flesh per day. Nitrogen and phosphorus in prey was also estimated based on the $M$. senhousia composition (Table 2). This suggests that the average wintering population of Aythya spp. consumes $3.5 \times 10^{10} \mathrm{M}$. senhousia individuals during their stay. This predation by diving ducks most likely induced the extinction of $M$. senhousia in the lagoon (Fig. 4).

Table 4. Estimated number of Musculista senhousia eaten per month by 3 species of Aythya spp. wintering in Lake Nakaumi from October 1 to March 31, and the amount of carbon, nitrogen, and phosphorus contained in $M$. senhousia flesh

\begin{tabular}{|lccc|}
\hline $\begin{array}{l}\text { Month } \\
\text { (no. of } \\
\text { days) }\end{array}$ & $\begin{array}{c}\text { Number of } \\
\text { M. senhousia }\end{array}$ & $\begin{array}{c}\text { Nitrogen (t) } \\
\text { contained in } \\
\text { M. senhousia } \\
\text { flesh }\end{array}$ & $\begin{array}{c}\text { M. sentained in } \\
\text { flesh }\end{array}$ \\
\hline October (31) & $1.14 \times 10^{10}$ & 10.0 & 0.772 \\
November (30) & $6.21 \times 10^{9}$ & 8.97 & 0.646 \\
December (31) & $4.44 \times 10^{9}$ & 9.27 & 0.722 \\
January (31) & $5.64 \times 10^{9}$ & 8.91 & 0.613 \\
$\begin{array}{l}\text { February (28) } \\
\text { March (31) }\end{array}$ & $3.80 \times 10^{9}$ & 7.12 & 0.521 \\
Total & $3.59 \times 10^{9}$ & 7.58 & 0.567 \\
\hline
\end{tabular}

Most nitrogen (52 t) and phosphorus (3.8 t) in the flesh of Musculista senhousia would be excreted into Lake Nakaumi as feces and urine because the accumulation in ducks is small. Although excreted nutrients may stimulate the growth of phytoplankton, total nitrogen and phosphorus concentrations in Lake Nakaumi do not usually increase during the ducks' stay (Kato et al. 1996). Because water exchange with the sea is estimated to be $16 \mathrm{~d}$ (Kamiya 1988), excreted nutrients would not contribute to the growth of phytoplankton in warmer seasons. Feces accumulated at the bottom of the lagoon hardly induced bottom-water anoxia in winter (Metocean Co. 1994).

Without the diving ducks, the huge Musculista senhousia biomass would likely die in summer due to anoxia as often happens in Lake Nakaumi because water stratification develops easily at this time (Metocean Co. 1994). M. senhousia predators are generally absent in Lake Nakaumi in spring and summer because carnivorous invertebrates (i.e. crabs, shrimps, and gastropods) escape to the ocean during the cold season and only few return to water with a low oxygen 
concentration in warmer seasons. $M$. senhousia death by suffocation in summer would add a certain nitrogen and phosphorus load to the lagoon in the form of mussel flesh. Mussel flesh decomposition at the bottom in summer would also accelerate oxygen depletion, which would increase nutrient efflux from sediment.

In terms of calories, the biofouling mussel Musculista senhousia is a better food source for ducks than the commercial clam Corbicula japonica because their shells are much thinner. Mean flesh caloric values were nearly identical- $17.6 \mathrm{~kJ} \mathrm{~g}^{-1}$ for $M$. senhousia and $18.1 \mathrm{~kJ} \mathrm{~g}^{-1}$ for C. japonica. M. senhousia, which lives above the sediment in high densities, would also be easier for ducks to collect than infaunal clams.

In Lake Nakaumi, biofouling mussel predation by diving ducks during winter thus may prevent water quality from deteriorating due to mussel death during summer, when nuisance phytoplankton blooms and anoxia occur easily.

Acknowledgements. We thank Mr Yoshio Sekiya for his assistance with field surveys, and the Shimane Prefectural Institute of Public Health and Environmental Science for providing laboratory facilities.

\section{LITERATURE CITED}

Cooper J (1980) Energetic requirements for maintenance of a captive juvenile great white pelican Pelecanus onocrotalus. Cormorant 8:17-19

De Vaate AB (1991) Distribution and aspects of population dynamics of the zebra mussel, Dreissena polymorpha (Pallas, 1771), in the lake IJsselmeer area (The Netherlands). Oecologia 86:40-50

Doornbos G, Groenendijk AM, Jo YW (1986) Nakdong estuary barrage and reclamation project: preliminary results of the botanical, macrozoobenthic and ornithological studies. Biol Conserv 38:115-142

Erwin RM (1996) Dependence of waterbirds and shorebirds on shallow-water habitats in the Mid-Atlantic coastal region: an ecological profile and management recommendations. Estuaries 19:213-219

Editorial responsibility: Otto Kinne (Editor), Oldendorf/Luhe, Germany
Hilgerloh G (1997) Predation by birds on blue mussel Mytilus edulis beds of the tidal flats of Spiekeroog (southern North Sea). Mar Ecol Prog Ser 146:61-72

Kamiya $H$ (1988) Volume estimation on saline water intrusion to Lake Shinji and Lake Nakaumi. Report of the Shimane Prefectural Institute of Public Health and Environmental Science, No. 30, p $94-95$

Kato K, Godo T, Kageyama A, Ashiya R, Ishitobi Y (1996) Water qualıty of Lake Shinji and Lake Nakaumi. Report of the Shimane Prefectural Institute of Public Health and Environmental Science, No. 38, p 111-114.

Kim HC, Won PO (1994) Ecology of waterbirds on the Naktong River Estuary, Korea. Korean J Ornithol 1:57-71

Kooyman GL, Davis RW, Croxall JP, Costa DP (1982) Diving depths and energy requirements of king penguins. Science 217:726-727

Lasiewski RC, Dawson WR (1967) A re-examination of the relation between standard metabolic rate and body weight in birds. Condor 69:13-23

Manny BA, Johnson WC, Wetzel RG (1994) Nutrient additions by waterfowl to lakes and reservoirs: predicting their effects on productivity and water quality. Hydrobiologia 279/280:121-132

Marion L, Clergeau P, Brient L, Bertru G (1994) The importance of avian-contributed nitrogen $(\mathrm{N})$ and phosphorus (P) to Lake Grand-Lieu, France. Hydrobiologia 279/280: $133-147$

Metocean Co. (1994) Preliminary report on assessment of water quality of Lake Shinji and Lake Nakaumi, III 1-48. Metocean Co, Tokyo

Nakamura M, Yamamuro M, Ishikawa M, Nishimura $H$ (1988) Role of the bivalve Corbicula japonica in the nitrogen cycle in a mesohaline lagoon. Mar Biol 99:369-374

Perry MC, Deller AS (1996) Review of factor affecting the distribution and abundance of waterfowl in shallow-water habitats of Chesapeake Bay. Estuaries 19:272-278

Sawamura T, Nakamura M, Nakao S, Yamane K (1993) Aquatic environment and macrobenthos community in Lake Nakaumi. Bull Shimane Prefect Fish Exp Stn 1991:201-211

Sewell MA (1996) Detection of the impact of predation by migratory shorebirds: an experimental test in the Fraser River estuary, British Columbia (Canada). Mar Ecol Prog Ser 144:23-40

Stańczykowska A, Zyska P, Dombrowski A, Kot H, Zyska E (1990) The distribution of waterfowl in relation to mollusc populations in the man-made Lake Zegrzyńskie. Hydrobiologia 191:233-240

Submitted: March 26, 1998; Accepted: August 25, 1998

Proofs received from author(s): November 10, 1998 